\title{
EFFECTIVENESS OF HYDROMULCHING TO REDUCE RUNOFF AND EROSION IN A RECENTLY BURNT PINE PLANTATION IN CENTRAL PORTUGAL
}

\author{
Sérgio Alegre Prats ${ }^{1 *}$, Maruxa Cortizo Malvar ${ }^{1}$, Diana Catarina Simões Vieira ${ }^{1}$, Lee MacDonald ${ }^{2}$, Jan Jacob Keizer ${ }^{1}$ \\ ${ }^{1}$ Centro de Estudos do Ambiente e do Mar (CESAM), Department of Environment and Planning, University of Aveiro, 3810-193 Aveiro, Portugal \\ ${ }^{2}$ Department of Forest, Rangeland and Watershed Stewardship, Warner College of Natural Resources, Colorado State University, Fort Collins, \\ CO 80523-1472, USA
}

Received: 13 June 2013; Revised: 4 July 2013; Accepted: 4 July 2013

\begin{abstract}
Forest fires can greatly increase runoff and surface erosion rates. Post-fire soil erosion control measures are intended to minimize this response and facilitate ecosystem recovery. In a few recent cases, hydromulch has been applied, and this consists of a mixture of organic fibers, water and seeds. The objectives of this research were to (i) analyze the effectiveness of hydromulch in reducing post-fire runoff and sediment production and (ii) determine the underlying processes and mechanisms that control post-fire runoff and erosion. After a wildfire occurred in August 2008, 14 plots ranging in size from $0 \cdot 25$ to $10 \mathrm{~m}^{2}$ were installed on a 25 degree slope in a burnt pine plantation that had also been subjected to salvage logging. Half of the plots were randomly selected and treated with hydromulch. One of two slope strips adjacent to the plots was also hydromulched and used for monitoring some soil properties. Measurements made in each of the first 3 years following the wildfire included (i) the plot-scale runoff volumes and sediment yields; (ii) soil shear strength, soil moisture, and soil water repellency; and (iii) surface cover. The hydromulch reduced overland flow volume by $70 \%$ and soil erosion by $83 \%$. The decrease in runoff was attributed to the increase in soil water retention capacity and the decrease in soil water repellency, whereas the reduction in soil erosion was initially attributed to the protective cover provided by the hydromulch and lately to an enhanced vegetative regrowth in the third year after burning. Copyright $\odot 2013$ John Wiley \& Sons, Ltd.
\end{abstract}

KEYWORDS: wildfire; post-fire erosion; overland flow; soil water repellency; ash

\section{INTRODUCTION}

Soil erosion is a key process in the functioning of Mediterranean ecosystems (Cantón et al., 2001; Ceballos et al., 2003; Cerdà et al., 2010), and wildfires represent one of a number of disturbances in forests and shrublands that can greatly increase soil and fertility losses (Cerdà, 1998a, 1998b; Shakesby \& Doerr, 2006; Shakesby, 2011). The consumption of the vegetation and litter layer by fire increases both overland flow-because of the reduction of rainfall interception and resistance to flowand sediment losses by increasing the splash erosion by raindrops (Soto \& Diaz-Fierros, 1997; Llorens \& Domingo, 2006). Additionally, the fire-induced heating of the soil can reduce aggregate stability, decrease porosity, and increase soil water repellency (SWR), and these changes can decrease infiltration and increase soil erodibility (DeBano, 2000; Ferreira et al., 2008; Keizer et al., 2008; Malvar et al., 2011; Prats et al., 2012).

The association of wildfire with on-site soil erosion and downstream flooding and massive sediment deposition has become increasingly recognized (Kraebel, 1934) and, in the early part of the last century, led to the first systematic soil erosion control treatments following wildfires (Munns, 1919). The first post-fire rehabilitation efforts consisted of

*Correspondence to: S. A. Prats, Centro de Estudos do Ambiente e do Mar (CESAM), Department of Environment and Planning, University of Aveiro, 3810-193 Aveiro, Portugal.

E-mail: sergio.alegre@ua.pt building engineering structures (check dams) in stream channels to trap the sediments and of seeding hillslopes to increase ground cover (Wohlgemuth et al., 2009). However, it was proved to be unrealistic to build check dams in the short periods between the occurrence of the wildfires and the occurrence of the erosion-producing rains; also, various studies started to question the effectiveness of seeding to reduce soil erosion during the 1980s (Gautier, 1983; Taskey et al., 1989).

During the 1990s and the 2000s, research on post-fire erosion mitigation concerned seeding (e.g., Pinaya et al., 2000; Fernández-Abascal et al., 2003; Beyers, 2004; Robichaud et al., 2006; Groen \& Woods, 2008; Peppin et al., 2010), construction of erosion barriers by using logs (Wagenbrenner et al., 2006; Robichaud et al., 2008), and straw mulching (Bautista et al., 1996; Badía \& Martí, 2000; Wagenbrenner et al., 2006). In a nutshell, these studies found seeding to be effective in some cases but not in others, $\log$ erosion barriers to be ineffective unless rain events are few and small, and mulching to be highly effective. The effectiveness of mulching was also well-established for agriculture lands (Harris \& Yao, 1923; Meyer et al., 1970; Lyles et al., 1974; Meyer et al., 1999; Wilson et al., 2004; García-Orenes et al., 2009, 2010; Giménez-Morera et al., 2010; Jordán et al., 2010), cut slopes, and unpaved roads (Grismer \& Hogan, 2005; Jordán \& Zavala, 2008).

Post-fire straw mulching at rates of c.a. $2 \mathrm{Mgha}^{-1}$ has been proved to reduce sediment yields by more than $80 \%$ 
(Bautista et al., 1996; Badía \& Martí, 2000; Wagenbrenner et al., 2006; Groen \& Woods, 2008; Fernández et al., 2011; Robichaud et al., 2013b). However, straw may be available in only limited quantities in certain regions, including Portugal (Prats et al., 2012), and may be redistributed by strong winds as a result of its low weight (Robichaud et al., 2000). Straw application can also introduce invasive weeds and inhibit native species recovery (Kruse et al., 2004). Despite the increased application costs, other mulches of higher specific weight have also been tested. Forest residues, at application rates of $8 \mathrm{Mg} \mathrm{ha}^{-1}$ in Prats et al. (2012) and $46 \mathrm{Mgha}^{-1}$ in Shakesby et al. (1996), or wood strands mulch, at rates of $4-12 \mathrm{Mgha}^{-1}$ in Robichaud et al. (2013a), were found to be as effective as straw mulch, whereas wood chips mulch was found to be much less effective (Kim et al., 2008; Fernández et al., 2011).

Mulching is effective against erosion because it reduces runoff and erosion rates by two mechanisms. First, it increases interception storage capacity, which reduces the amount of rain available for producing runoff, it reduces runoff velocity, and it increases soil moisture (Bautista et al., 2009). Second, mulch protects the soil surface against the kinetic energy of rainfall drops and decreases the hydrodynamic power of flowing water (Smets et al., 2008).

A recent variant of mulching is that of hydromulching, which refers to the application of a water-based mixture of organic fibers, seeds and a green colorant. It is easily applied because it can be sprayed onto slopes by a jet hose (Naveh, 1975). It also tends to bind strongly to the soil surface by the action of the soil-binding agent, so it is particularly useful on steep slopes and strongly modified areas such as quarries, construction sites, and cut and fill slopes along roads (Emanual, 1976; Benik et al., 2003; Robichaud et al., 2010). Runoff and soil erosion will be reduced because the hydromulch increases interception storage and protects the soil surface. Additionally, the introduced seeds are intended to increase the vegetative cover, especially when the mulch starts decompose. In burnt areas, seeding requires careful selection of species that are adapted to the target environment, both to guarantee that the seeding produces an adequate cover and to avoid that the introduced species come to behave as invasive weed (Kruse et al., 2004). An important disadvantage of hydromulching is its elevated costs, which can range from $\$ 3,700.00$ to $\$ 10,300.00$ per ha for aerial application (Hubbert et al., 2012). By contrast, the costs for straw mulching are on the order of $\$ 600.00$ and $\$ 1,200.00$ per ha for application by helicopter and by hand-spreading, respectively (Napper, 2006). Despite this greater expense, hydromulching has been used especially in the USA after some fires when access was difficult, the slopes were too steep or subject to wind to use straw mulch and when there were particularly important 'values at risk', such as water reservoirs, cultural or natural heritage sites, or industrial plants.
The effectiveness of hydromulching in reducing post-fire runoff and erosion has not yet been fully established. Although Robichaud et al. (2013b) found no marked decrease in post-fire runoff, Hubbert et al. (2012), Rough (2007), and Robichaud et al. (2010, 2013a) did report substantial reductions in erosion rates (with 65-95\%). However, these reductions were restricted to the first year after hydromulching, which the authors attributed to the rapid breakdown of the mulch layer. Wohlgemuth et al. (2011) also found hydromulching to markedly reduce overall erosion rates (by $60-80 \%$ ) but not the sediment losses produced by high-intensity storms. Robichaud et al. (2010) suggested that hydromulching would be most effective on short slopes $(10-20 \mathrm{~m})$, where interrill erosion is the dominant process and the hydromulch mat is less likely to be detached by rill incision. However, Rough (2007) found aerial hydromulching to be highly effective on long hillslopes with elevated rill densities $\left(0 \cdot 1\right.$ rill m$\left.^{-2}\right)$.

Given the elevated potential of hydromulching for postfire rehabilitation, there is a clear need to test its effectiveness in geographical regions outside the USA. Although hydromulch can include surfactants, the effectiveness of hydromulching has been poorly assessed for vegetation types associated with strong or extreme SWR, such as the eucalypt and pine plantations that dominate in north-central Portugal (Ferreira et al., 2008, Keizer et al., 2008; Prats et al., 2012). Also, the effectiveness of hydromulching after post-fire salvage logging is poorly known in spite of being perhaps the most common practice following wildfires in north-central Portugal. Salvage logging was typically being used to recover timber values and reduce the risk of insect infestation (McIver \& Starr, 2000), but it can trigger runoff and soil erosion through soil alteration and forest floor disturbances (Rab, 1994; Castillo et al., 1997; Edeso et al., 1999; Fernández et al., 2004, 2007).

The overall aim of the present research was to study the effectiveness of hydromulching to reduce runoff and erosion over a three-year period in a recently burnt and logged pine plantation in north-central Portugal. The specific objectives were to (i) assess the effectiveness of hydromulching in reducing runoff volumes and sediment yields at the plot scale; (ii) analyze the changes in runoff and soil erosion over time and across plot size $(0.25,0 \cdot 5$, and $10 \mathrm{~m}^{2}$ plots); and (iii) determine the effect of hydromulching on key soil properties, surface cover, and vegetative recovery, and the extent to which these mulching-induced changes can explain the observed differences in runoff and erosion between the hydromulched and untreated plots.

\section{MATERIAL AND METHODS}

\section{Study Area and Site}

This study was conducted near the village of Colmeal in the Góis municipality of north-central Portugal (N 40 $08^{\prime} 42^{\prime \prime}, \mathrm{W}$ 7059'16"; $490 \mathrm{~m}$ asl). On 27 August 2008, a wildfire burnt 68 ha of forest lands. A west-facing 25 degree steep hillslope 
was selected to study post-fire vegetation recovery (Maia et al., 2012a, 2012b), and, at a later stage, also for this study. The hillslope had been planted with maritime pine (Pinus pinaster Ait.) some 25 years before the wildfire, at a density of 2,600 saplings per ha. The undergrowth was composed of a mixture of Mediterranean and Atlantic shrubs and was dominated by Calluna vulgaris I. and Arbutus unedo L. (Maia et al., 2012b). The study area has a Mediterranean climate with a mean annual temperature of $10-12.5^{\circ} \mathrm{C}$ (according to Köppen; APA, 2011). The annual precipitation as recorded by the nearest weather station (Cadafaz, $\mathrm{N}$ $40^{\circ} 08^{\prime} 02^{\prime \prime}, \mathrm{W} 8^{\circ} 32^{\prime} 40^{\prime \prime} ; 12 \mathrm{~km} \mathrm{~W}^{-1}$ from the study area; 25 years of data) was, on average, $1,130 \mathrm{~mm}$ but varied from $717 \mathrm{~mm}$ to $1,872 \mathrm{~mm}$ (SNIRH, 2012). The soils were shallow, 30- to 35-cm deep Humic Cambisols (WRB, 2007), overlying schist, as was observed from four soil pits dug during November 2008 (Table I). A soil sample was collected at $0-5 \mathrm{~cm}$ depth in each pit, and later analyzed, using standard laboratory methods, for bulk density (Porta et al., 2003), porosity, and grain-size distribution (Guitian \& Carballas, 1976). Percent organic carbon was determined by a carbon analyzer (Flash EA 1112 series by Thermo Finnigan, USA) and multiplied by the van Bemmelen factor $(1.724)$ in order to obtain the organic matter content on the soil (Jackson, 1958).

\section{Experimental Design, Field Data Collection, and} Laboratory Analyses

At the location selected for this experiment, the 2008 wildfire had completely consumed the pine crowns, so

Table I. Indicators of fire severity, ground cover, and mean soil properties from 0 - to 5 -cm depth $(n=4)$

\begin{tabular}{|c|c|c|c|}
\hline Site characteristics & Average & \pm & SD \\
\hline Overall fire severity & \multicolumn{3}{|c|}{ Moderate } \\
\hline Tree canopy consumption & \multicolumn{3}{|c|}{ Total } \\
\hline TDI & $0 \cdot 4$ & \pm & $0 \cdot 1$ \\
\hline $\operatorname{MTR}\left({ }^{\circ} \mathrm{C}\right)$ & 78 & \pm & 30 \\
\hline \multicolumn{4}{|c|}{ Ground cover in December $2008(\%)$} \\
\hline Litter & 2 & \pm & $1 \cdot 3$ \\
\hline Black ashes & $56 \cdot 6$ & \pm & $9 \cdot 7$ \\
\hline Bare soil & $7 \cdot 2$ & \pm & $3 \cdot 7$ \\
\hline Stones $(>2 \mathrm{~mm})$ & $34 \cdot 2$ & \pm & $8 \cdot 3$ \\
\hline \multicolumn{4}{|l|}{ Soil properties } \\
\hline Soil depth (cm) & $35 \cdot 3$ & \pm & $4 \cdot 3$ \\
\hline Slope $\left({ }^{\circ}\right)$ & $24 \cdot 5$ & \pm & $3 \cdot 4$ \\
\hline Bulk density $\left(\mathrm{g} \mathrm{cm}^{-3}\right)$ & $0 \cdot 8$ & \pm & $0 \cdot 1$ \\
\hline Porosity $\left(\mathrm{cm}^{3} \mathrm{~cm}^{-3}\right)$ & $0 \cdot 5$ & \pm & $0 \cdot 1$ \\
\hline Organic matter $(\%)$ & $16 \cdot 4$ & \pm & $1 \cdot 6$ \\
\hline \multicolumn{4}{|l|}{ Soil texture } \\
\hline Clay $(\%)$ & $8 \cdot 4$ & \pm & 1.9 \\
\hline Silt $(\%)$ & $35 \cdot 8$ & \pm & $9 \cdot 0$ \\
\hline Sand $(\%)$ & $55 \cdot 8$ & \pm & $12 \cdot 8$ \\
\hline Stoniness (>2 mm) (\%) & 36 & \pm & $15 \cdot 0$ \\
\hline USDA soil texture class & \multicolumn{3}{|c|}{ Sandy loam } \\
\hline
\end{tabular}

TDI, twig diameter index; MTR, maximum temperature reached, following Maia et al. (2012a, 2012b); SD, standard deviation; USDA, United States Department of Agriculture. there was basically no needle cast after the fire (Table I). On 11 December 2008, 106 days after the fire, more than half of the soil surface corresponded to black ashes, a third to stones, and less than $10 \%$ to bare soil. The fire severity was classified as moderate according to various severity indices described in Maia et al. (2012b) at locations some 5-10 m distance from the present experiment. For example, the maximum temperature reached (Guerrero et al., 2007) by the soil at 0-3 cm depth, estimated with near-infrared spectroscopy, was, on average, $78^{\circ} \mathrm{C}$; the twig diameter index ( Maia et al., 2012a), which ranged between 0 (unburnt) and 1 (very intense wildfire) was, on average, $0 \cdot 4$ (Table I).

Because the National Forestry Authority had decided to $\log$ the stand as soon as possible because of the risk of nematode infestation, the experimental set up of this study involved four phases. The first phase comprised the installation of a tipping-bucket rain gage (Pronamic professional rain gauge with an event logger) in combination with a storage gage for validation purposes. This was carried out on 15 September 2008, prior to any rainfall following the wildfire. After that, the rainfall was measured weekly from the storage gage, and the maximum weekly or monthly 30-min rainfall intensity (' $\mathrm{I} 30$ ', in $\mathrm{mm} \mathrm{h}^{-1}$ ) was calculated for each period from the tipping-bucket rain gage data series.

On 5 November 2008, the pretreatment period started with the installation of four plots bounded with metal sheets. Two were micro-plots of approximately $0.5 \times 0.5 \mathrm{~m}$, whereas the other two were small plots of approximately $0.5 \mathrm{~m}$ wide and $1.0 \mathrm{~m}$ long. The outlets of each plot were connected, using garden hose, to $30 \mathrm{~L}$ tanks, where the runoff was collected. The runoff volume in each tank was measured at 1- to 2-weekly intervals, depending on rainfall, from 5 November 2008 to 12 October 2010, except during March 2008 when the runoff measurements had to be interrupted because of the logging activities. This 23-month period was divided in a pretreatment and posttreatment period, as further specified in Table II. Whenever runoff exceeded $250 \mathrm{ml}$, a sample was collected for determination of sediment and organic matter contents by using standard laboratory methods (filtration at $14 \mu \mathrm{m}$, drying for $24 \mathrm{~h}$ at $105^{\circ} \mathrm{C}$ and loss-on-ignition for $4 \mathrm{~h}$ at $550^{\circ} \mathrm{C}$; APHA, 1998).

The third phase began on 30 March 2009, after the logging had been completed, when two more micro-plots and two more small plots were installed at close distances from the previous micro-plots $(<5 \mathrm{~m})$ along with six sediment fences (Robichaud \& Brown, 2002) that had been set up at some 10-20 m distance in the upslope direction. Following the design by Fernández et al. (2011), these sediment fence plots ('SF plots') of roughly 2-m wide and 5-m long were bounded by means of a geotextile fabric and delimited by metal sheets to avoid run-on into the plots. The geotextile fabric filtered the runoff, and only the sediments accumulated at the bottom of the SF plots were collected at monthly intervals from 31 March 2009 to 12 October 2010. Afterwards, the SF plots were emptied 
Table II. Overall figures of rainfall, overland flow, soil losses, and effectiveness of hydromulching during the first 3 years after a wildfire in a maritime pine plantation

\begin{tabular}{|c|c|c|c|c|c|}
\hline \multirow{2}{*}{ Period } & & \multicolumn{2}{|c|}{ Year 1} & \multirow{2}{*}{$\begin{array}{c}\text { Year } 2 \\
\text { Post }\end{array}$} & \multirow{2}{*}{$\begin{array}{c}\text { Year } 3 \\
\text { Post }\end{array}$} \\
\hline & & Pre & Post & & \\
\hline Start date & & 5 November 2008 & 31 March 2009 & 21 September 2009 & 12 October 2010 \\
\hline End date & & 11 February 2009 & 21 September 2009 & 12 October 2010 & 28 November 2011 \\
\hline Rainfall (mm) & & 609 & 282 & 1464 & 1527 \\
\hline \multicolumn{6}{|l|}{ Overland flow } \\
\hline 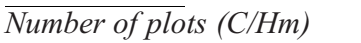 & & $4 / 0$ & $4 / 4$ & $4 / 4$ & - \\
\hline \multirow[t]{2}{*}{ Runoff (mm) } & $\mathrm{C}$ & 363 & 140 & 691 & - \\
\hline & $\mathrm{Hm}$ & - & 61 & 152 & - \\
\hline \multirow{2}{*}{ Runoff coefficient $(\%)$} & $\mathrm{C}$ & 60 & 50 & 47 & - \\
\hline & $\mathrm{Hm}$ & - & 22 & 10 & - \\
\hline \multicolumn{6}{|l|}{ Erosion } \\
\hline 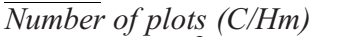 & & $4 / 0$ & $7 / 7$ & $7 / 7$ & $3 / 3$ \\
\hline \multirow[t]{2}{*}{ Soil loss $\left(\mathrm{g} \mathrm{m}^{-2}\right)$} & $\mathrm{C}$ & 86 & 217 & 361 & 247 \\
\hline & $\mathrm{Hm}$ & - & 36 & 63 & 109 \\
\hline Specific soil loss & $\mathrm{C}$ & $0 \cdot 14$ & 0.77 & $0 \cdot 25$ & $0 \cdot 16$ \\
\hline$\left(\mathrm{g} \mathrm{m}^{-2} \mathrm{~mm}\right.$ rain $\left.^{-1}\right)$ & $\mathrm{Hm}$ & - & $0 \cdot 13$ & $0 \cdot 04$ & $0 \cdot 07$ \\
\hline \multirow[t]{2}{*}{ Organic matter content $(\%)$} & $\mathrm{C}$ & 48 & 50 & 52 & - \\
\hline & $\mathrm{Hm}$ & - & 57 & 57 & - \\
\hline Effectiveness of & Runoff & - & -56 & -78 & - \\
\hline \multirow{2}{*}{ hydromulching ( $\%$ change) } & Soil losses & - & -83 & -83 & -56 \\
\hline & OM \% & - & 15 & 10 & - \\
\hline
\end{tabular}

C, control; Hm, hydromulching; OM, organic matter.

on a single occasion, on 28 November 2011, comprising the fourth phase of this study. The collected sediments were later analyzed for their moisture and organic matter contents by using standard laboratory methods (drying for $24 \mathrm{~h}$ at $105^{\circ} \mathrm{C}$ and loss-on-ignition for $4 \mathrm{~h}$ at $550^{\circ} \mathrm{C}$; APHA, 1998).

On 31 March 2009, the hydromulch was applied to two of the four micro-plots, two of the four small plots, and three of the six SF plots, all of which were selected randomly. In addition, it was applied to one of two adjacent soil strips of 5-m wide and 10-m long, which had been delineated for monitoring of selected soil properties by using destructive techniques. The hydromulch was provided and applied by Serraic, Lda. by using a jet hose operated by a person on foot. It consisted of an aqueous mixture of wood fibers, seeds, a surfactant, nutrients, a natural bio-stimulant and a green colorant applied at a nominal ratio of $3.5 \mathrm{Mg} \mathrm{ha}^{-1}$. The formulation is confidential, but the company guaranteed that the components are nontoxic for humans or the environment. The seed composition was also confidential, but detailed descriptions of the floristic composition in the SF plots suggested that it included grass (e.g., Lolium perenne L.) as well as shrub species [Cytisus striatus (Hill), Ulex minor Roth.].

Ground cover was measured at seven occasions between 31 March 2009 and 12 October 2010 and finally on 11 November 2011. The ground cover was recorded at each intersection point of a $5 \times 5-\mathrm{cm}$ grid in the case of the micro-plots and small plots, and of a $10 \times 10-\mathrm{cm}$ grid in the case of the SF plots, that is, at 100, 200, and 400 points, respectively. Each recording involved classifying the ground cover according to seven categories: stones bigger than $2 \mathrm{~mm}$ ('Stone'), bare soil ('Bare'), ashes ('Ash'), litter ('Litter'), hydromulch ('Hm'), native vegetation ('Natveg'), and vegetation introduced by hydromulch ('Introveg'). The data also were grouped into two lumped categories: total vegetation ('Tveg') and total protective ground cover ('Hlv'), with the latter being the sum of hydromulch, litter, and vegetation.

The soil strips were sampled at monthly intervals from 22 April 2009 to 11 August 2010 for a total of 17 occasions. Sampling involved destructive measurements of soil shear strength, using a torvane (vane tester, Eijkelkamp), and of SWR, using the molarity ethanol drop (Doerr, 1998). At the bottom of each $50 \mathrm{~m}^{2}$-strip, 15 equally spaced measurements were made along a horizontal transect, and this transect was then shifted approximately $0.5 \mathrm{~m}$ upslope for the next sampling occasion. Before measuring shear strength or repellency, any hydromulch, stones, litter, or ashes were removed. The molarity ethanol drop test was slightly modified in accordance with our prior studies (e.g., Keizer et al., 2005a, 2005b, 2008). In this study, three drops of pure water were applied to the soil surface, and, if two of the three drops did not infiltrate within $5 \mathrm{~s}$, three drops with successively higher ethanol concentrations were applied until two of the three drops infiltrated within $5 \mathrm{~s}$. The nine ethanol concentrations used were $0,1,3,5,8 \cdot 5,13,18,24$, and $36 \%$. In data analysis, the overall median of the relative frequency of any ethanol concentrations higher than $0 \%$, calculated over the total measurements in each strip, was called SWR frequency.

Volumetric soil moisture content was monitored at a depth of $0-5 \mathrm{~cm}$ at eight locations: four within the untreated SF plots and four within the hydromulched SF plots. This 
was carried out using eight EC-5 sensors linked to two Em5b data loggers (Decagon Devices, Inc.) and recording data at $10 \mathrm{~min}$ intervals. For each read-out period, initial soil moisture content ('Sm') was calculated as the soil moisture at the start of the largest rainfall event during that 1- to 2weekly period by using the data of the automatic rainfall gage to identify this event.

\section{Data Analysis}

For the statistical analyses described in the succeeding text, runoff volumes and (specific) soil losses were fourth-root transformed so that the residuals did not fail the assumption of normality according to the Kolmogorov-Smirnov test at $\alpha \leq 0.05$, whereas runoff coefficients were square-root transformed for the same reason. Furthermore, 16 read-outs with low rainfall amounts (less than $6 \mathrm{~mm}$ ) had to be removed from the data set to prevent non-normality of the residuals.

The effects of hydromulching, plot size, and time-sincehydromulching on the dependent variables (runoff volume, runoff coefficient, soil losses, specific soil losses, and organic matter content of the eroded sediments) were assessed by means of a three-way repeated measures analysis of variance (ANOVA) (Ott \& Longnecker, 2001). The variance-covariance structure of each dependent variable was selected according to the lowest values of the Akaike information criterion and the restricted maximum likelihood (REML) fit (Littell et al., 2006). The heterogeneous firstorder auto-regressive variance-covariance structure was selected for all dependent variables except runoff coefficient, for which a spatial power structure was selected. In addition, specific contrasts between the treated and control plots, for each individual read-out as well as between the three plot sizes, were tested by means of the least squares means and adjusted by the Tukey-Kramer method (Kramer, 1956). Repeated measures ANOVA was also used to test the treatment and time effects on the seven ground cover categories and the initial soil moisture content. In the case of soil resistance and SWR frequency, however, the treatment effect could only be tested using a nonparametric test, that is, the Mann-Whitney $U$-test $(\alpha \leq 0 \cdot 05)$.

Stepwise multiple linear regressions using the REG procedure in SAS (Littell et al., 1996) were used to determine how well the weekly runoff volumes $(n=35)$ and the monthly soil losses $(n=17)$ could be explained by a set of independent variables. These variables were selected sequentially in a forward selection procedure, in order of decreasing significance by using a minimum $p$ value of $0 \cdot 05$. The 16 independent variables were plot size ('Plotsz'), rainfall amount ('Rain'), 30-min maximum rainfall intensity ('I30'), days since the last rainy day ('Drain'), the seven individual ('Stone', 'Bare', 'Ash', 'Litter', 'Hm', 'Natveg', and 'Introveg'), the two lumped categories ('Tveg' and 'Hlv'), soil shear strength ('Storv'), SWR frequency, and initial soil moisture content ('Sm'). Especially because the various cover categories can be expected to reveal strong correlations, collinearly tests were included in the stepwise procedure, removing independent variables with a condition index higher than 30 (Belsley et al. 1980) from the regression models.

\section{RESULTS}

\section{Rainfall Amount and Intensity}

Rainfall was considerably lower during the first year after the wildfire $(1,014 \mathrm{~mm})$ than during the two subsequent years $(1,464$ and $1,527 \mathrm{~mm}$, respectively; Table II). Even though this study did not commence until 8 December 2008 and had to be interrupted, because of the salvage logging, during March 2009, the present analysis covered almost $90 \%$ of the rainfall during the first post-fire year (891 mm; Figure 1). From these $891 \mathrm{~mm}, 609 \mathrm{~mm}$ fell before the logging and the hydromulch application (designated here as 'pretreatment period'), and 282 were measured until the end of post-fire year 1 . The highest rainfall amounts were measured during winter, in January 2009 and 2010 with 244 and $262 \mathrm{~mm}$, respectively. The highest rainfall intensities, however, occurred during different times of the first

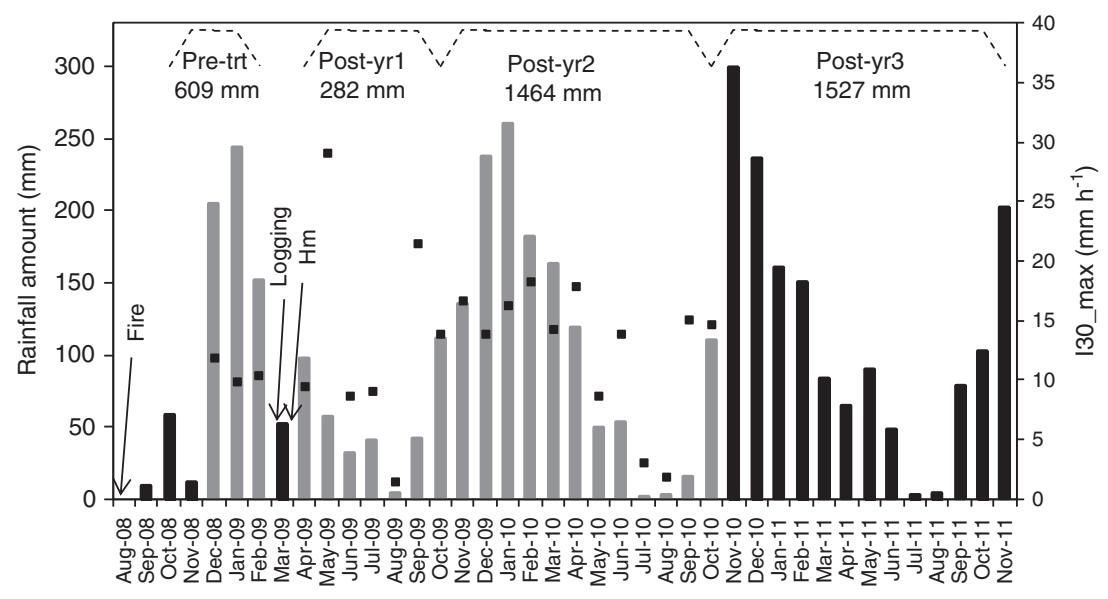

Figure 1. Monthly rainfall (mm) and maximum monthly 30-min rainfall intensity over the study period. Black columns represent total rainfall where no rainfall intensity data were collected. Arrows indicate the date of the fire, logging, and the hydromulch application (Hm), respectively. 
post-fire year, during May 2009 and September 2009 with maximum $\mathrm{I} 30$ of $29 \mathrm{~mm} \mathrm{~h}^{-1}$ and $21 \mathrm{~mm} \mathrm{~h}^{-1}$. During the second post-fire year, I30s of $15 \mathrm{~mm} \mathrm{~h}^{-1}$ occurred at least once a month from October 2009 to April 2010.

\section{Ground Cover}

At the start of this study, in December 2008, half of the soil surface was covered by ashes, and less than $10 \%$ was bare (Figure 2; Table I). By 26 March 2009, after the logging had been completed, ash cover had decreased to $28 \%$, the bare soil cover had increased to $17 \%$, and the stones had become the predominant cover category with, on average, $42 \%$. The recovery of the vegetation was very slow on the control plots, as vegetative cover continued to be near zero 1 year after the fire (August 2009), but reached 30\% after the second year (October 2010) and a mere 36\% at the beginning of the fourth post-fire year (November 2011). Immediately after its application, on 31 March 2009, the hydromulch provided a cover of $80 \%$ on average, but this cover was significantly higher at the two micro-plots and two small plots $(90 \% \pm 4 \%)$ than at the three SF plots $(64 \% \pm 2)$ (ANOVA, $p<0 \cdot 05)$. This difference was no longer significant after five months (August 2009), even though the hydromulch cover continued higher at the four runoff plots $(64 \% \pm 12)$ than at the three SF plots $(47 \% \pm 7$; ANOVA, $p=0.06)$. There was a marked decrease $(5.3 \%$ per month) in the average of the hydromulch cover during the first 5 months after its application. After 1 year from the application (1 April 2010), the hydromulch cover decreased to $27 \%$ on average (an annual decay rate of $4.6 \%$ per month). This decrease in hydromulch cover was, by and large, compensated by an increase in protective soil cover due to the native and introduced vegetation (including the litter it produced). The cover of the introduced vegetation was at its maximum (22\%) in June 2010 and became practically zero by November 2011. The native vegetation recovered slowly on the hydromulched plots as well but by
November 2011 did attain a clearly higher cover than at the control plots (52\% vs. $36 \%$ ). The total protective ground cover (lumped into the 'hlv' category) was around $75 \%$ through all the post-treatment period. When the stone cover is included, a protective layer consistently covered $90 \%$ of the surface.

\section{Soil Properties}

The monthly values of soil shear strength, frequency of SWR, as well as the soil moisture content over the posttreatment period are depicted in Figure 3. The three variables oscillated across the monitoring period according to the rainfall amounts. Soil shear strength and soil moisture varied in the wake of the rainfall variations. By contrast, SWR showed the lowest values during the rainiest months.

Overall, soil resistance to detachment was lower at the untreated than treated strip $\left(2.4 \pm 0.7 \mathrm{~kg} \mathrm{~cm}^{-2}\right.$ vs. $2 \cdot 8 \pm 0.5 \mathrm{~kg} \mathrm{~cm}^{-2} ; \quad U$-test: $\left.Z=-5.04 ; \quad p<0 \cdot 01\right)$. Shear strength was clearly lowest at the control strip during 12 out of 17 months as opposed to 2 months at the hydromulched strip, when shear strength was also greater than during the remaining months.

The hydromulched strip, overall, was less repellent than the control $(15 \%$ vs. $35 \%$ SWR frequency; $U$-test: $Z=-6 \cdot 07 ; p<0 \cdot 01)$ and consequently had higher soil moisture $(18.1 \%$ volume \pm 9.7 vs. $14.3 \% \pm 6.7$; ANOVA: $F=7$; $p<0.05)$. In certain periods, however, the opposite was true, as is well-illustrated by Figure 3. In the case of soil moisture content, these periods were confined to the dry season of summer 2009; in the case of SWR, it also happened during summer 2010 .

\section{Overall Runoff and Soil Losses}

Roughly half of the rainfall was converted into runoff on the control plots (Table II). This corresponded to $360 \mathrm{~mm}$ of runoff [runoff coefficient $(\mathrm{rc})=60 \%$ ] during the pretreatment period, $140 \mathrm{~mm}$ during the post-treatment

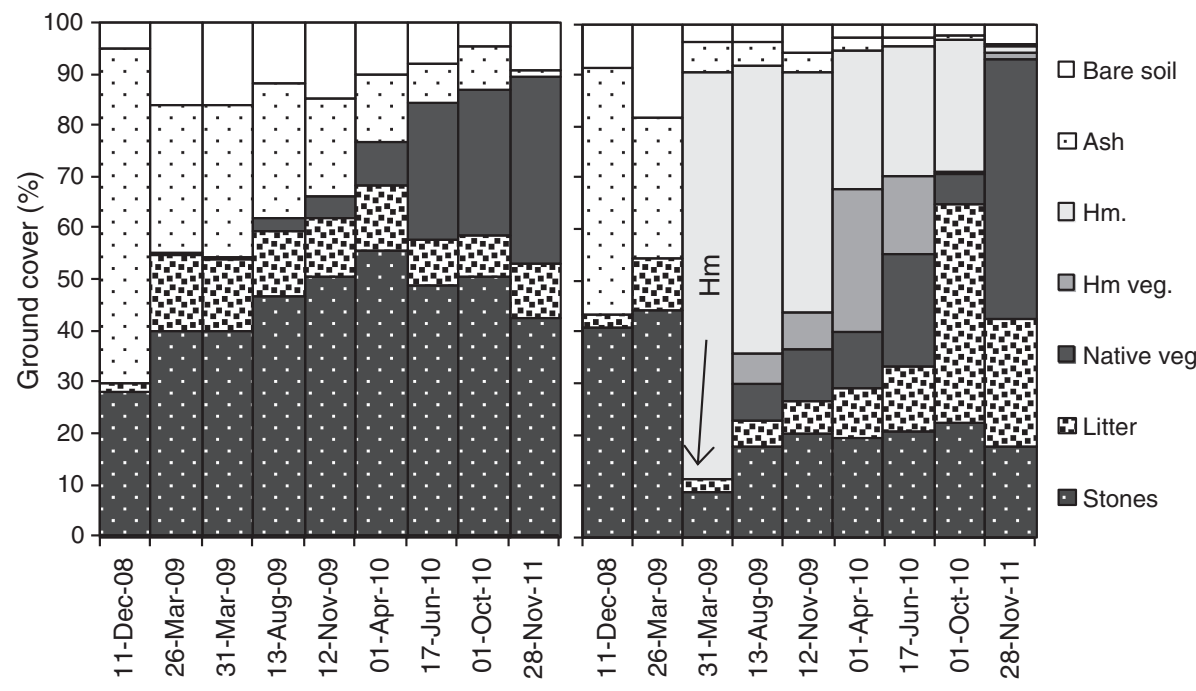

Figure 2. Mean ground cover (\%) of the seven categories analyzed in the seven control plots (left) and seven hydromulched plots (right). The arrow indicates the date of the hydromulch application $(\mathrm{Hm})$. 


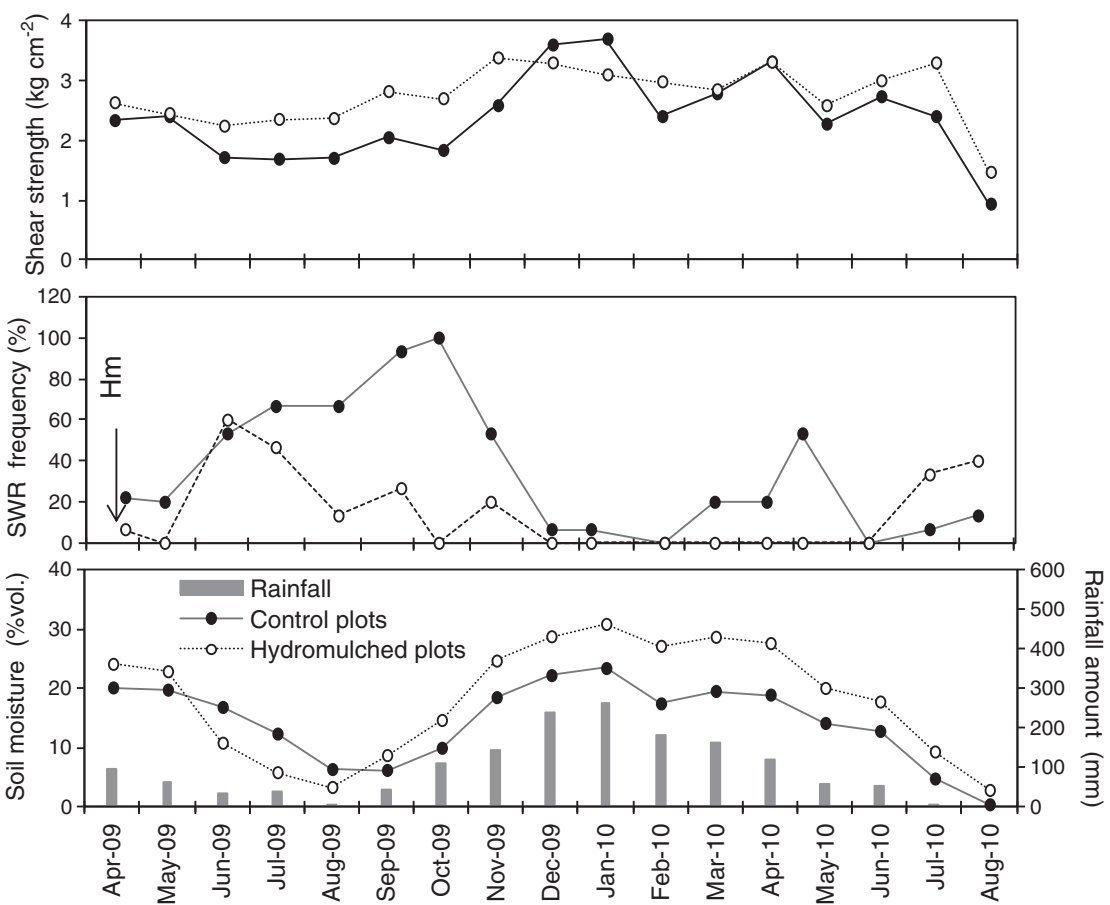

Figure 3. Monthly average values of soil shear strength (top), frequency of soil water repellency (middle) and initial soil moisture content (i.e., prior to rainfall events) and rainfall (bottom) for the control and hydromulched strips.

period of the first post-fire year $(\mathrm{rc}=50 \%)$, and $691 \mathrm{~mm}$ during the second post-fire year $(\mathrm{rc}=47 \%)$. These differences coincided with the variations in rainfall amount. However, the same was not true in the case of soil losses. The control plots produced, on average, $86 \mathrm{~g} \mathrm{~m}^{-2}$ during the pre-treatment period, $217 \mathrm{~g} \mathrm{~m}^{-2}$ during the post-treatment period of the first post-fire year, and $361 \mathrm{~g} \mathrm{~m}^{-2}$ during the second post-fire year. There was a fivefold increase in the specific soil losses between the pre-treatment and post-treatment periods (from 0.14 to $0.77 \mathrm{~g} \mathrm{~m}^{-2} \mathrm{~mm} \mathrm{rain}^{-1}$ ), and after that, the specific soil losses decreased progressively until reaching values similar to those prior to the logging during the third year $\left(0 \cdot 16 \mathrm{~g} \mathrm{~m}^{-2} \mathrm{~mm} \mathrm{rain}^{-1}\right.$; Table II).
Hydromulching was highly effective in reducing overland flow, with, on average, 56\% during the first post-fire year and even 78\% during the subsequent year (Table II). Hydromulching effectiveness in decreasing soil losses exceeded the effectiveness at reducing overland flow to a marked extent, amounting to $83 \%$ during both years. During the third post-fire year, however, the effectiveness in mitigating erosion reduced to $56 \%$. Hydromulching did, however, increase somewhat the relative amounts of organic matter in the eroded sediments to $57 \%$ as opposed to $50 \%$ and $52 \%$.

The ANOVA analysis of Table III showed that the treatment effect strongly influenced all the variables, especially

Table III. Summary of the three-way repeated measures analysis of variance of the 1- to 2-weekly runoff amounts (fourth-root transformed), runoff coefficients (square-root transformed), as well as of the monthly soil losses, specific soil losses (fourth-root transformed) and organic matter contents of the eroded sediments during the posttreatment period (31 March 2009-12 October 2010)

\begin{tabular}{|c|c|c|c|c|c|c|c|}
\hline $\begin{array}{l}\text { Variable } \\
\text { Unit } \\
n\end{array}$ & $\begin{array}{l}\text { Df num, } \\
\text { den }\end{array}$ & $\begin{array}{c}\text { Runoff amount } \\
\text { mm } \\
35\end{array}$ & $\begin{array}{c}\text { Runoff } \\
\text { coeffient } \\
\% \\
35\end{array}$ & $\begin{array}{c}\text { Df num, } \\
\text { den }\end{array}$ & $\begin{array}{c}\text { Soil losses } \\
\mathrm{g} \mathrm{m}^{-2} \\
17\end{array}$ & $\begin{array}{c}\begin{array}{c}\text { Specific soil } \\
\text { losses } \\
\mathrm{g} \mathrm{m}^{-2} \mathrm{~mm}^{-1} \text { rain } \\
17\end{array}\end{array}$ & $\begin{array}{c}\text { Organic matter } \\
\text { content } \\
\% \\
17\end{array}$ \\
\hline Treatment & 1,4 & $80 \cdot 2$ & $176 \cdot 3$ & 1,8 & $71 \cdot 7$ & $63 \cdot 7$ & $9 \cdot 3$ \\
\hline Size & 1,4 & $1 \cdot 0$ & $0 \cdot 0$ & 2,8 & $3 \cdot 3$ & $2 \cdot 6$ & $2 \cdot 7$ \\
\hline Size*treatment & 1,4 & $3 \cdot 2$ & $3 \cdot 9$ & 2,8 & $1 \cdot 7$ & $1 \cdot 4$ & $0 \cdot 3$ \\
\hline Time & 34,136 & $116 \cdot 6$ & $17 \cdot 3$ & 16,124 & $27 \cdot 8$ & $21 \cdot 2$ & $3 \cdot 0$ \\
\hline Treatment*time & 34,136 & $8 \cdot 4$ & $3 \cdot 2$ & 16,124 & $5 \cdot 0$ & $4 \cdot 5$ & $\overline{1.9}$ \\
\hline Size*time & 34,136 & $\overline{2 \cdot 1}$ & $\overline{0.7}$ & 30,124 & $\overline{3 \cdot 8}$ & $\overline{3 \cdot 6}$ & $1 \cdot 7$ \\
\hline Size*treatment*time & 34,136 & $\overline{2 \cdot 1}$ & $1 \cdot 1$ & 30,124 & $\overline{3 \cdot 1}$ & $\overline{3 \cdot 0}$ & 1.5 \\
\hline
\end{tabular}

Df, degrees of freedom; num, numerator; den, denominator.

The $F$ values in bold, or both in bold, and underlined were statistically significant at $\alpha=0.05$ and $0 \cdot 01$, respectively. 
in the case of runoff coefficient ( $F$ value of 176) and less important in the case of the organic matter content $(F=9)$. The strong treatment effect, especially in the case of runoff coefficient as highlighted by the big $F$ value (176), contrasted with the lack of effect of the plot size.

In Figure 4 it can be observed that the differences in runoff between plot sizes were very low (in the order of 12-20\%, for micro-plots and small plots, respectively). The runoff on the control plots decreased with increasing plot size mainly because of the low runoff amount of one of the small plots $(684 \mathrm{~mm})$, whereas the same was true but in the opposite sense in the case of one small hydromulched plot $(309 \mathrm{~mm})$. These opposite tendencies resulted in a higher hydrological effectiveness of hydromulching for the micro-plots compared with the small plots (on average, $80 \%$ vs. $68 \%$ ). Plot size also did not play a clear-cut role in soil losses, but the variance increased, especially in the case of the control SF plots (up to 70\%). Consequently, the overall reduction in soil losses on the micro-plots and small plots was somewhat higher compared with the SF plots $(90 \%, 89 \%$, and $76 \%$, respectively).

\section{Temporal Patterns in Overland Flow and Soil Losses}

The average monthly runoff amounts produced by the untreated plots revealed a marked seasonal pattern in which peak runoff values appeared to antecede the maximum monthly rainfall values during the winter season (Figure 5a). As a result, runoff coefficients were highest during the autumn months, varying between about $80 \%$ to $90 \%$ in December 2008, November 2009, and October 2010. High runoff coefficients were also observed during late spring and early summer, when rainfall amounts were comparatively small $(<53 \mathrm{~mm})$, attaining $62 \%$ in July 2009 and $81 \%$ in June 2010 . The average monthly soil losses at the untreated plots revealed a less obvious temporal pattern (Figure 5b). The four peak losses of $50 \mathrm{~g} \mathrm{~m}^{-2}$ month $^{-1}$ or more occurred during autumn (December 2008, September and November 2009) and spring (May 2009). Apparently, the latter peak was associated with the elevated maximum rainfall intensity $\left(\mathrm{I} 30=29 \mathrm{~mm} \mathrm{~h}^{-1}\right)$, whereas the December 2008 and November 2009 ones were rather related to runoff peaks. The average specific soil losses suggested a contrast between the two months with the highest maximum rainfall intensities - that is, May and September 2009-and the remaining months. The specific losses during these two months amounted to 0.8 and $1.2 \mathrm{~g} \mathrm{~m}^{-2} \mathrm{~mm} \mathrm{rain}^{-1}$, respectively, as opposed to the baseline monthly average of $0 \cdot 25 \mathrm{~g} \mathrm{~m}^{-2} \mathrm{~mm} \mathrm{rain}^{-1}$ for the rest of the study period.

The hydromulched plots produced, on average, consistently lower amounts of monthly runoff as well as monthly soil losses than the untreated plots (Figure $5 \mathrm{a}$ and $5 \mathrm{~b}$ ). In the case of runoff, these monthly differences were statistically significant from July 2009 onwards, with the exception of the summer 2009 and 2010 months with little to no rainfall. In the case of soil losses, however, the monthly differences were also statistically significant for the first 2 months following hydromulching and, thus, for basically all of the 19 months with noticeable rainfall. Even so, the three-way ANOVA results indicated that hydromulching did not have an unequivocal statistically significant effect on monthly soil losses, as the triple interaction term of treatment $\mathrm{x}$ time-since-mulching $x$ plot size was statistically significant (Table III). The same applied to the corresponding specific soil losses as well as to the 1- to 2-weekly runoff volumes and mutatis mutandis (i.e., because of a significant treatment $x$ time-since-mulching interaction) to the runoff coefficients and the organic matter content of the eroded sediments.

Hydromulching failed to produce significant reductions in overland flow generation (average 1- to 2-weekly values) across the whole range of maximum rainfall intensities (Figure 6). There was, however, a tendency for the hydrological effectiveness of hydromulching to decrease with maximum rainfall intensity, reflecting first and foremost the comparatively low effectiveness $(<50 \%)$ for the two more intense measurement periods that happened in May and September 2009. Also, the effectiveness of hydromulching to reduce average monthly soil losses was comparatively low for these two highest maximum rainfall intensities, albeit it still amounted to some $80 \%$ and corresponded to a statistically significant difference between the hydromulched and untreated plots. In overall terms, however, the reduction in soil losses lacked an obvious relationship with rainfall intensity.
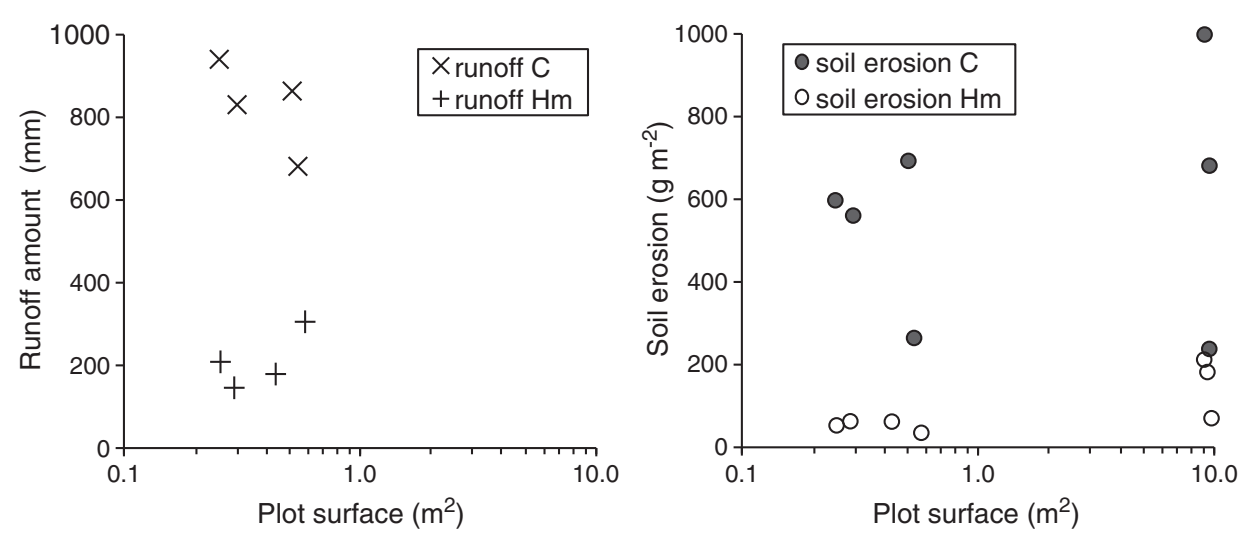

Figure 4. Total overland flow $(\mathrm{mm})$ and total soil losses $\left(\mathrm{g} \mathrm{m}^{-2}\right)$ of the individual untreated and hydromulched plots over the first and second year of the posttreatment period (31 March 2009 to 12 October 2010). 

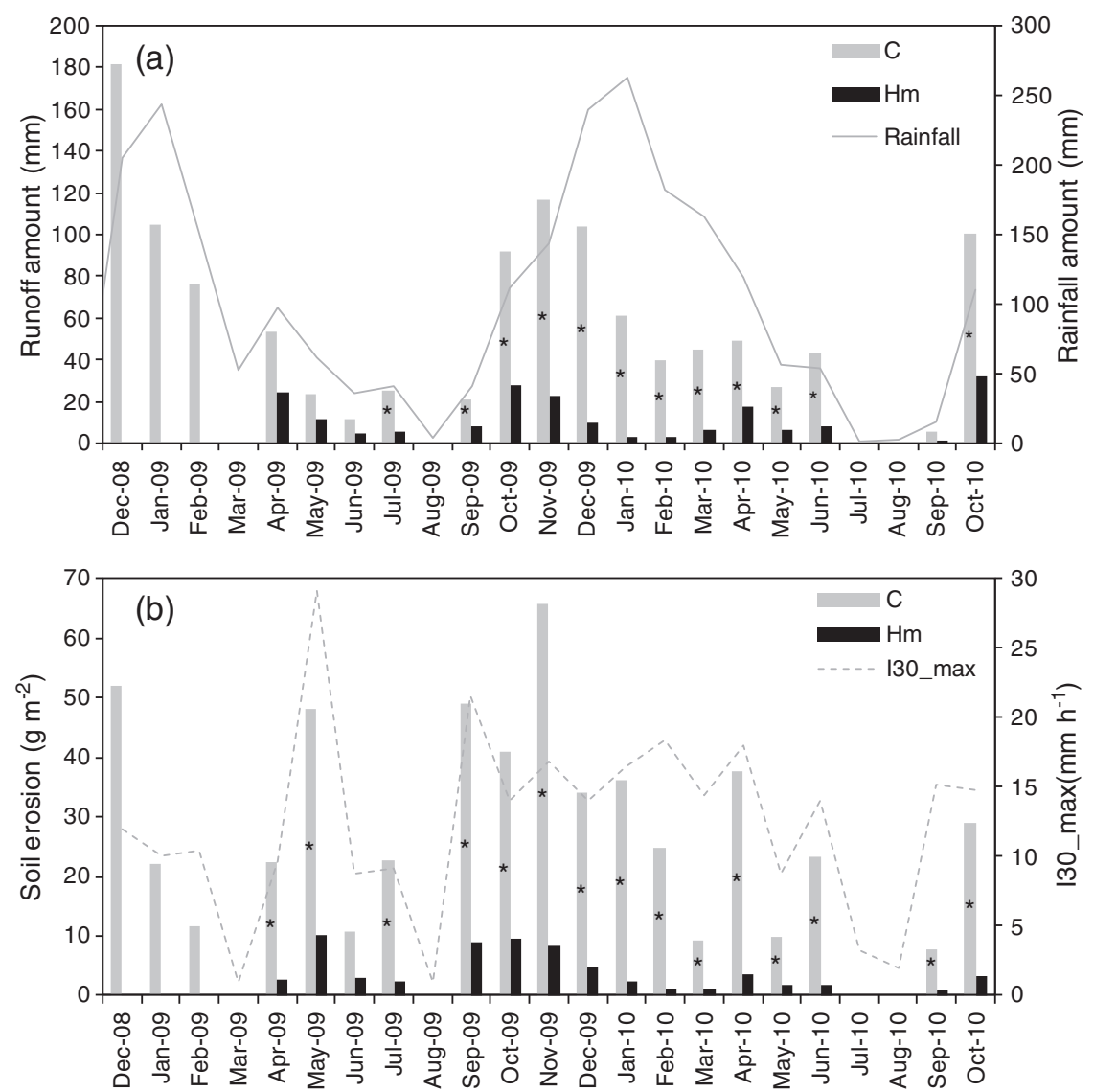

Figure 5. Average monthly values of rainfall ( $\mathrm{mm})$ and overland flow (mm) (5a) and of 30-min maximum rainfall intensity (I30; mm ${ }^{-1}$ ) and soil losses $\left(\mathrm{g} \mathrm{m}^{-2}\right)(5 \mathrm{~b})$ for the untreated and hydromulched plots from the fourth through the twenty-sixth month after the wildfire. Asterisks denote significant least squares mean differences between hydromulched and control plots $(p<0.05)$.

\section{Key Factors Explaining Runoff and Soil Losses}

Stepwise multiple linear regression with all eight hydromulched and untreated runoff plots together ('global model') revealed that the total protective ground cover

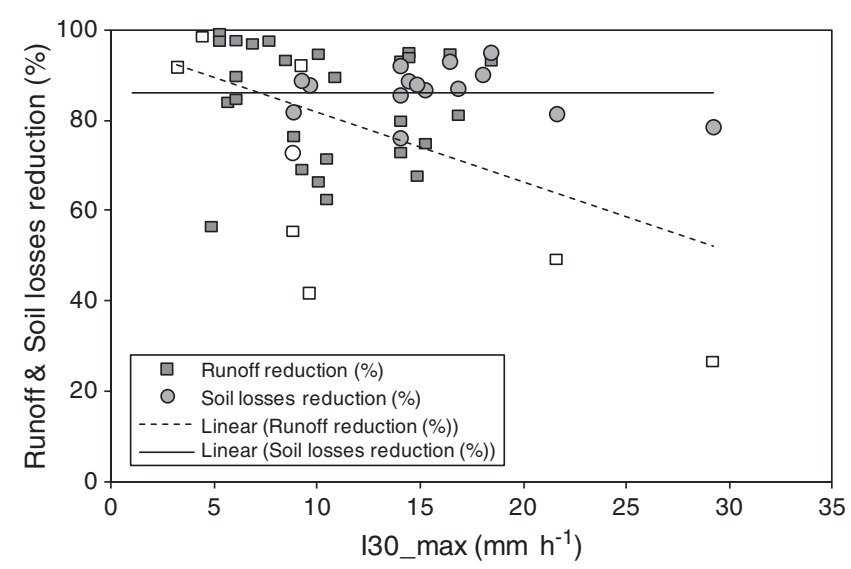

Figure 6. Weekly runoff (squares) and monthly soil losses (circles) reductions at the hydromulched plots compared with untreated plots in relation to 30-min maximum rainfall intensity for the posttreatment period (31 March 2009 to 12 October 2010). Gray-filled/white-filled symbols correspond to significant/not significant least squares mean differences between control and hydromulched plots (at $\alpha=0 \cdot 05$ ). Dotted and continuous lines correspond to linear regression equations fitted to runoff and soil loss reductions, respectively. ('hlv') stood out as the principal factor in overland flow generation, explaining more than twice as much of the variation in fourth-root transformed runoff amount than the second factor, I30 (31\% vs. 13\%; Table IV). The hydrological response of the untreated plots alone, however, could clearly be explained best by rainfall amount $(41 \%$ of variance), whereas that of the hydromulched plots alone was mainly controlled by maximum rainfall intensity, albeit to a lesser degree (19\% of variance). Initial soil moisture content was the second most important (and significant) explanatory variable of the runoff produced by the untreated but not the hydromulched plots. The negative sign of its coefficient suggested that the role of initial soil moisture was indirect, with SWR increasingly enhancing overland flow generation as soils dry out. Figure 7 illustrated well that the hydrological response of the untreated plots was stronger under drier than wetter soil conditions. A similar tendency was suggested for the hydromulched plots but just for rainfall amounts below $60 \mathrm{~mm}$, as higher rainfall amounts were associated with wetter soils at the hydromulched than untreated strips.

The predominant role of total protective ground cover ('hlv') was even more pronounced in the case of the global model for soil losses than that for runoff volumes, explaining over half of the variation (55\%; Table IV). The most conspicuous contrast between the erosion and runoff 


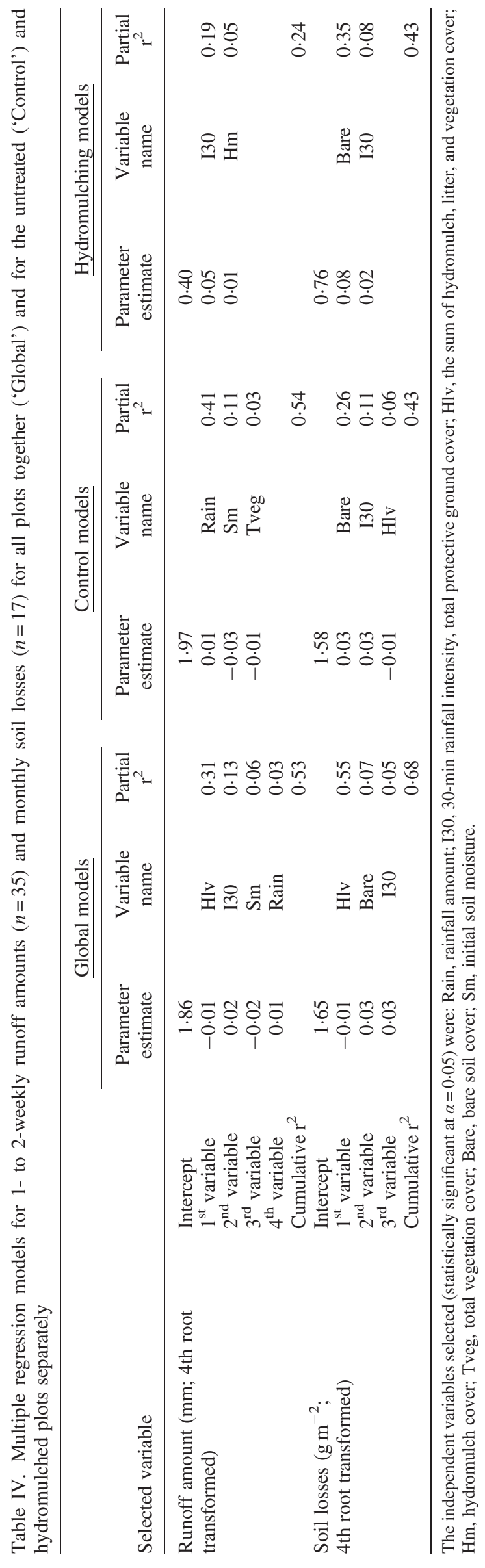



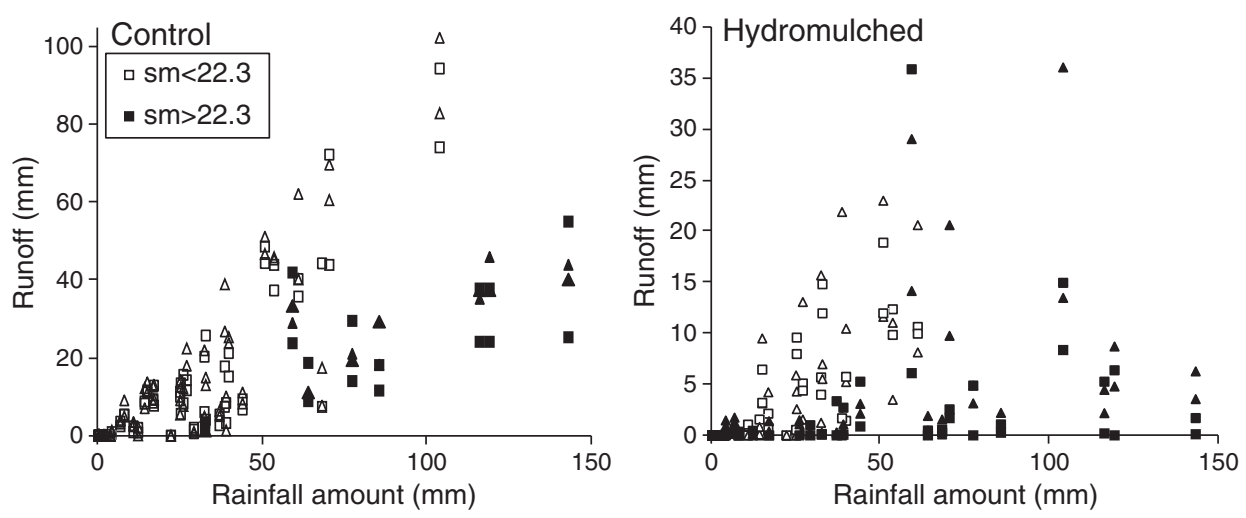

Figure 7. Runoff versus rainfall amounts for the untreated (left) and hydromulched (right) micro-plots (triangles) and small plots (squares) under contrasting initial soil moisture conditions, of less versus greater than $22.3 \%$ (open and filled symbols, respectively). Note the different scales of the two Y axes.

results, however, was evidenced by the treatment-specific models. Bare soil cover clearly outranked rainfall amount/ intensity as the prime factor explaining soil losses, not only at the untreated plots ( $26 \%$ vs. $11 \%$ of variance) but also at the hydromulched plots ( $35 \%$ vs. $8 \%$ of variance).

\section{DISCUSSION}

\section{Post-Fire Hydrological and Erosion Response in Pine Sites} of Central Portugal

Post-fire runoff coefficients as high as observed here were also reported by previous studies in north-central Portugal, such as Ferreira et al. (2008) and Malvar et al. (2011) by using rainfall simulation experiments. Both prior studies related their strong hydrological response to extreme SWR. In the present study, however, the role of SWR would be limited to the first year after the wildfire, when repellency was moderate, and mostly hydrophilic after November 2009. This reduced importance of SWR was also suggested by the multivariate linear regression model that was fitted to the runoff data from the control plots. The global regression model attested that it was rather ground cover that played a key role in overland flow generation. Pierson et al. (2009) likewise argued that ground cover exerted a greater influence on post-fire hydrological response than SWR. Various studies in Portugal (Shakesby et al., 1996; Ferreira et al., 2008; Prats et al., 2012) have furthermore attributed low post-fire runoff coefficients in pine stands to needle cast from scorched tree crowns (Shakesby et al., 1996; Cerdà \& Doerr, 2008; Ferreira et al., 2008; Prats et al., 2012).

The soil losses from the control plots during the first postfire year $\left(302 \mathrm{~g} \mathrm{~m}^{-2}\right)$ were higher than the range of 80-220 $\mathrm{g} \mathrm{m}^{-2}$ year $^{-1}$ reported by other studies in burnt pine plantations (Shakesby et al., 1996; Fernández et al., 2007; Ferreira et al., 2008; Prats et al., 2012). This could be due to the salvage logging activities that took place during late winter/early spring 2009, as was also suggested by the markedly higher specific soil losses immediately after logging than during the pretreatment period. Logging-enhanced erosion rates were also reported by Inbar et al. (1997) and suggested by Malvar et al. (2013) but not by Fernández et al. (2007). The latter authors attributed their findings to the low severity of the fire, the low rainfall erosivity, and the reduced perturbations of the soil by the machinery employed. To minimize the erosion effects of post-fire logging, it is widely recommended to delay the logging activities until litter fall from scorched tree canopies has provided a 'natural' mulching (Rab, 1994; Castillo et al., 1997; Edeso et al., 1999; Fernández et al., 2004, 2007; Cerdà \& Doerr, 2008).

The soil losses during the first post-fire year fitted in well with the low values that were reported by Shakesby (2011) for moderate severity on field plots in the Mediterranean region $\left(321 \mathrm{~g} \mathrm{~m}^{-2}\right.$ year $\left.^{-1}\right)$, which was attributed to an intensive land-use history. By contrast, in regions of lower forest interventions such as North America, post-fire erosion rates can be one order of magnitude higher, amounting to 2,500 $\mathrm{g} \mathrm{m}^{-2}$ year $^{-1}$ (Spigel \& Robichaud, 2007). The discrepancy between these two geographical regions seems to be much smaller for organic matter losses, with values of 200 and $150 \mathrm{~g} \mathrm{~m}^{-2}$ year $^{-1}$. High losses of organic matter are of particular relevance as they can easily compromise soil fertility and, thus, on-site land-use sustainability and downstream surface water quality through pollution with toxic pyrogenic organic compounds (Vila-Escalé et al., 2007; Campos et al., 2012).

A protective ground cover was also the most important factor explaining the monthly soil losses observed in this study and the differences therein between the treated and untreated plots. This agreed well with the bulk of post-fire soil erosion studies (e.g., Benavides-Solorio \& MacDonald, 2001; Pannkuk \& Roubichaud, 2003; Benavides-Solorio \& MacDonald, 2005; Fernández et al., 2008; Larsen et al., 2009). At the same time, bare soil cover played a key role in the differences in soil losses among the hydromulched plots, as well as among the control plots. Pietraszek (2006) equally attested to the relevance of bare soil cover for soil losses from untreated areas. It could explain 50\% of the variability in soil erosion produced by ten sites that had burnt from less than one up to 10 years earlier. 


\section{Effectiveness of Hydromulching in Reducing Runoff and Soil Losses}

The hydromulch was a complex mixture which contained water, wood fibers, seeds, surfactants, seed-growing biostimulants, nutrients and a green colorant. It is intended that each component affected some of the pieces of the post-fire runoff erosion process.

Runoff was highly reduced at the treated plots, between $56 \%$ and $73 \%$, which is higher than in other post-fire mulching experiments, both with straw (Bautista et al., 1996; Groen \& Woods, 2008) and forest residues (Shakesby et al., 1996; Prats et al., 2012). Probably, this high effectiveness could be related to the effect of the wood fibers, because it increases the surface water storage capacity, but also due to the effect of the surfactants, a wetting agent that reduces SWR and increases soil infiltration (Leighton-Boyce et al., 2007; Madsen et al., 2012).

Soil losses were highly reduced in the hydromulch plots during the 3 years after the wildfire. Ground cover was pointed out as the main factor controlling soil losses, but the hydromulch mat showed a rapid decay during the first year after the application. This was identified as one of the disadvantages of hydromulchings (MacDonald \& Robichaud, 2007). In the present study, the decayment rates of the hydromulch ranged between $4 \%$ and $6 \%$ per month, very similar to other research with hydromulch (Hubbert et al., 2012; Robichaud et al., 2013a). In contrast to those sites, our hydromulch was highly conducive to germination and growth of plants from seeds. Thus, the introduced seeds compensated for the loss of hydromulch with progressively more plant and litter cover, which resulted in more than $70 \%$ protective ground cover since the hydromulch application until the third post-fire year (Figure 2).

Besides the composition, the application technique can influence the hydromulch effectiveness. In this study, the area was already logged and the plots were small, which a priori will facilitate the spread of the hydromulch from a jet hose operated on foot. However, the hydromulch cover was significantly lower on the SF plots despite being sufficient to reduce soil erosion. Rough (2007) and Robichaud et al. (2010) reported that the hydromulch sprayed from vehicles was intercepted by the standing trees, and they recommended special caution when applying the mixture in areas with a high density of dead trees and from long distances. Aerial hydromulch can be a better and less expensive option, but Hubbert et al. (2012) checked that the intended application rates of $50 \%$ and $100 \%$ hydromulch cover resulted in only $20-26 \%$ and $56 \%$.

Unsuccessful hydromulch experiences were first attributed to extreme rainfall events (Wohlgemuth et al., 2011) or to the long length of the plots (Napper, 2006). Robichaud et al. (2010) pointed out that hydromulch effectiveness depended on slope length, only being effective at slopes shorter than $10-20 \mathrm{~m}$, when interrill erosion was the dominant process instead of rill erosion. The former authors hypothesized that in their long slope sections, the smooth and dense hydromulch mat had little resistance against the sheer force of concentrated flow. But on the other hand, the research of Rough (2007) showed that aerial hydromulching was highly effective and was carried out at the hillslope scale $\left(2,500 \mathrm{~m}^{-2}\right.$, on average), where rills were frequent $\left(0 \cdot 1\right.$ rills $\left.\mathrm{m}^{-2}\right)$ and after extreme rainfall events $\left(\mathrm{I} 30=40 \mathrm{~mm} \mathrm{~h}^{-1}\right)$. Many other hydromulch formulations are available and are being evaluated for their capacity to reduce soil losses. As concluded by Robichaud et al. (2013a), the differences in hydromulch components, application techniques, and application rates can greatly impact hydromulch effectiveness. However, Napper (2006) referred that one of the major problems is the difficulty in knowing the specific chemical composition that was applied in a given situation because most of the hydromulch formulations are kept confidential.

\section{Hydromulching Effects in Soil Properties}

Soil properties in agriculture had been typically improved by mulching (Smets et al., 2008) by materials such as manure, stones, straw, forest residue, and wood shreds (Harris \& Yao, 1923; Mulumba \& Lal, 2008; Foltz \& Copeland, 2009). Regarding post-fire soil shear strength, the results are not conclusive. Bautista et al. (1996) and Fernández et al. (2011) found no differences between control and straw mulch plots. Fernández et al. (2007) found lower figures in logged compared to unlogged plots. They related these lower values to the absence of roots, once that the logged plots showed a much lower vegetation cover. Agreeing with them, the statistically higher soil shear strength measured on the hydromulch strip could be related to a higher vegetation cover compared to the control strip. Regarding soil water properties, our results are consistent with other mulch experiments (Smets et al., 2008; Bautista et al., 2009; Prats et al., 2012) in which higher soil moistures were found on the mulched areas. The hydromulching layer acted as a water adsorbent dense mat, which effectively increased the soil water retention capacity. It prevented sunlight from reaching the soil surface and thereby decreased soil temperatures. Still, the surfactants included on the hydromulch could have a role in increasing soil infiltration and improve the seed germination (Madsen et al., 2012). Besides the positive impacts over plant recovery and soil microbial activity (Bautista et al., 2009), a major insight suggested by Prats et al. (2012) supported the fact that mulching affected the SWR regime of the burnt forest, promoting the hydrophilic soil conditions. However, this was not true during the dry seasons. Probably, the higher plant cover of the hydromulch $(13 \%$ vs. $3 \%$ during the first post-fire summer) could increase the transpiration and thus lowering soil moisture and increasing SWR. Brainard et al. (2012) reported a higher water demand of plants during water stress periods in agriculture, and Soto \& DiazFierros (1997) found lower soil moisture on the vegetated areas as compared with bare and burnt plots during the first post-fire summer. 


\section{CONCLUSIONS}

The main conclusions of this study in the effectiveness of hydromulching to reduce runoff and erosion in a recently burnt and logged pine plantation were as follows: (i) hydromulching, providing coverage of $80 \%$, produced marked changes in SWR and soil moisture, especially in the soil cover. Despite a decrease of up to $30 \%$ after 1 year from the application, the treatment induced a highly protective ground cover because of an increase of both vegetative and litter cover; (ii) hydromulching was highly effective during the first 19 months after its application, reducing total runoff volumes by $70 \%$ and total soil losses by $83 \%$, and continued effectively during the third year following the wildfire, reducing erosion by $56 \%$; ( iii) hydromulching was less effective in reducing runoff (around 30\%) but not in reducing soil losses $(80 \%)$ for the more intense storms (I30 higher to $20 \mathrm{~mm} \mathrm{~h}^{-1}$ ); (iv) the protective soil cover provided by hydromulch, in combination with litter and vegetation, explained runoff and soil losses better than any other variable, however, rainfall intensity and soil moisture explained a considerable portion of the variation in runoff generation; (v) the application of hydromulch was lower than expected on the larger plots (only a 64\% hydromulch cover as compared with $90 \%$ in the smaller plots), despite both applications having significantly reduced soil losses. Further research will be needed to determine the effective ground cover in order to match hydromulch decayment rate and vegetative cover increase over time, especially to minimize application costs; and (vi) soil losses were similar across the range of plot sizes studied here $\left(0 \cdot 25-10 \mathrm{~m}^{2}\right)$. This, plus the small size of the plots, indicates that interrill erosion was the dominant erosion process. Further research is needed to determine how the effectiveness of hydromulching may vary with increasing slope length when rill erosion is more likely to occur.

\section{ACKNOWLEDGEMENTS}

We would like to thank especially the companies SerraicCreate and Innovate, Lda., Atlalusi Europe and USSA corporate, for freely providing and applying the hydromulch, the fire brigade of Arganil municipality for providing the water needed for producing the hydromulch, and the Forestry Office of Arganil and the Portuguese National Forestry Authority for giving authorization to carry out the experiment. The authors also gratefully acknowledge Paula Maia for her the active help with the floristic descriptions, Isabel Fernandes, Rosa Sjerps, and Alexandra Albuquerquer for their help with the fieldwork and laboratory analyses, and, more in general, to all of those who somehow contributed to the EROSFIRE-II project. This research was supported financially through the $\mathrm{PhD}$ grants attributed to SPA, (SFRH/BD/33392/2008), MMC (SFRH/ BD/41320/2007), and DCSV (SFRH/BD/65907/2009), by the Portuguese Foundation for Science and Technology
(FCT), in the framework of the IV program, as well as by the EROSFIRE-II project (PTDC/AGR-CFL/70968/2006), funded by the Portuguese Foundation for Science and Technology, with co-funding by FEDER through the POCI2010 Programme. We also wish to thank the two anonymous reviewers for their valuable help in improving this manuscript.

\section{REFERENCES}

APA: Agência Portuguesa do Ambiente. 2011. Valores Medios Anuais de Temperatura. http://sniamb.apambiente.pt/webatlas/. (Last accessed in December 2012).

APHA: American Public Health Association. 1998. Total suspended solids dried at $103-105^{\circ} \mathrm{C}$, method $2540 \mathrm{D}$. In Standard methods for the examination of water and wastewater, Clesceri LS, Greenberg AE, Eaton AD, Franson MAH (eds). 20th ed. Published jointly by American Public Health Association, American Water Works Association and Water Environment Federation: Washington D.C., U.S.A. ISBN: 0-87553-235-7

Badía D, Martí C. 2000. Seeding and mulching treatments as conservation measures of two burned soils in the central Ebro valley, NE Spain. Arid Soil Research and Rehabilitation 13: 219-232.

Bautista S, Bellot J, Vallejo VR. 1996. Mulching treatment for post-fire soil conservation in a semiarid ecosystem. Arid Soil Research and Rehabilitation 10: 235-242.

Bautista S, Robichaud PR, Bladé C. 2009. Post-fire mulching. In Fire effects on soils and restoration strategies, Cerdà A, Robichaud PR (eds). Science Publishers, Inc: Enfield, NH, USA; 353-372.

Belsley DA, Kuh E, Welsch RE. 1980. Regression diagnostics. John Wiley \& Sons: New York, USA.

Benavides-Solorio JD, MacDonald LH. 2001. Post-fire runoff and erosion from simulated rainfall on small plots, Colorado Front Range. Hydrological Processes 15: 2931-2952.

Benavides-Solorio JD, MacDonald LH. 2005. Measurement and prediction of post-fire erosion at the hillslope scale, Colorado Front Range. International Journal of Wildland Fire 14: 457-474.

Benik SR, Wilson BN, Biesboer DD, Hansen B, Stenlund D. 2003. Evaluation of erosion control products using natural rainfall events. Journal of Soil and Water Conservation 58: 98-105.

Beyers J. 2004. Postfire seeding for erosion control: effectiveness and impacts on native plant communities. Conservation Biology 18 947-956.

Brainard DC, Bakker J, Noyes DC, Myers N. 2012. Rye living mulch effects on soil moisture and weeds in asparagus. American Society of Horticultural Science 47: 58-63.

Campos I, Abrantes N, Vidal T, Bastos AC, Gonçalves F, Keizer JJ. 2012. Assessment of the toxicity of ash-loaded runoff from a recently burnt eucalypt plantation. European Journal of Forest Research 131: 1889-1903.

Cantón Y, Domingo F, Solé-Benet A, Puigdefábregas J. 2001. Hydrological and erosion response of a badland system in semiarid SE spain. Journal of Hydrology 252: 65-84.

Castillo VM, Martínez-Mena M, Albaladejo J. 1997. Runoff and soil loss response to vegetation removal in a semiarid environment. Soil Science Society of America Journal 61: 1116-1121.

Ceballos A, Cerdà A, Schnabel S. 2003. Runoff production and erosion processes on a dehesa in western Spain. Geographical Review 3: 333-353.

Cerdà A. 1998a. Postfire dynamics of erosional processes under Mediterranean climatic conditions. Zeitschrift für Geomorphologie 42: 373-398.

Cerdà A. 1998b. Changes in overland flow and infiltration after a rangeland fire in a Mediterranean scrubland. Hydrological Processes 12 1031-1042.

Cerdà A, Doerr SH. 2008. The effect of ash and needle cover on surface runoff and erosion in the immediate post-fire period. Catena 74: $256-263$.

Cerdà A, Hooke J, Romero-Diaz A, Montanarella L, Lavee H. 2010. Soil erosion on Mediterranean type-ecosystems. Land Degradation and Development 21: 71-74.

DeBano LF. 2000. The role of fire and soil heating on water repellency in wildland environments: a review. Journal of Hydrology 231: 195-206.

Doerr SH. 1998. On standardizing the "water drop penetration time" and the "molarity ethanol droplet" techniques to classify soil hidrophobicity: a case of study using medium textured soils. Earth Surface Processes and Landforms 23: 663-668. 
Edeso JM, Merino A, González MJ, Marauri P. 1999. Soil erosion under different harvesting managements in steep forestlands from northern Spain. Land Degradation and Development 10: 79-88.

Emanual DM. 1976. Hydromulch: a potential use for hardwood bark residue. USDA Forest Service Research Note NE-226.

Fernández C, Vega JA, Gras JM, Fonturbel T, Cuiñas P, Dambrine E, Alonso M. 2004. Soil erosion after Eucalyptus globulus clearcutting: differences between logging slash disposal treatments. Forest Ecology and Management 195: 85-95.

Fernández C, Vega JA, Fonturbel MT, Pérez-Gorostiaga P, Jiménez E, Madrigal J. 2007. Effects of wildfire, salvage logging and slash treatments on soil degradation. Land Degradation and Development 18: 591-607.

Fernández C, Vega JA, Fonturbel T, Jiménez E, Pérez JR. 2008. Immediate effects of prescribed burning, chopping and clearing on runoff, infiltration and erosion in a shrubland area in Galicia (NW Spain). Land Degradation and Development 19: 502-515.

Fernández C, Vega JA, Jiménez E, Fonturbel T. 2011. Effectiveness of three post-fire treatments at reducing soil erosion in Galicia (NW Spain). International Journal of Wildland Fire 20: 104-114.

Fernández-Abascal I, Tárrega R, Luis-Calabuig E, Marcos E. 2003. Effects of sowing native herbaceous species on the post-fire recovery in a heathland. Acta Oecologica 24: 131-138.

Ferreira AJD, Coelho COA, Ritsema CJ, Boulet AK, Keizer JJ. 2008. Soil and water degradation processes in burned areas: lessons learned from a nested approach. Catena 74: 273-285.

Foltz RB, Copeland NS. 2009. Evaluating the efficacy of wood shreds for mitigating erosion. Journal of Environmental Management 90: 779-785.

García-Orenes F, Cerdà A, Mataix-Solera J, Guerrero C, Bodí MB, Arcenegui V, Zornoza R, Sempere JG. 2009. Effects of agricultural management on surface soil properties and soil-water losses in eastern Spain. Soil and Tillage Research 106: 117-123.

García-Orenes F, Guerrero C, Roldán A, Mataix-Solera J, Cerdà A, Campoy M, Zornoza R, Bárcenas G, Caravaca F. 2010. Soil microbial biomass and activity under different agricultural management systems in a semiarid Mediterranean agroecosystem. Soil and Tillage Research 109: $110-115$.

Gautier CR. 1983. Sedimentation in burned chaparral watersheds: is emergency revegetation justified? Water Resources Bulletin 19: 793-801.

Giménez-Morera A, Ruiz Sinoga JD, Cerdà A. 2010. The impact of cotton geotextiles on soil and water losses in Mediterranean rainfed agricultural land. Land Degradation and Development 21: 210-217.

Grismer ME, Hogan MP. 2005. Simulated rainfall evaluation of revegetation/mulcherosion control in the Lake Tahoe Basin-3: soil treatment effect. Land Degradation and Development 16: 489-501.

Groen AH, Woods SW. 2008. Effectiveness of aerial seeding and straw mulch for reducing post-wildfire erosion, north-western Montana, USA. International Journal of Wildland Fire 17: 559-571.

Guerrero C, Mataix-Solera J, Arcenegui V, Mataix-Beneyto J, Gómez I. 2007. Near-infrared spectroscopy to estimate the maximum temperatures reached on burned soils. Soil Science Society American Journal 71: 1029-1037.

Guitian F, Carballas T. 1976. Técnicas de análisis de suelos, Pico Sacro: Santiago de Compostela, Spain; 288. ISBN: 84-85170-09-1

Harris FS, Yao HH. 1923. Effectiveness of mulches in preserving soil moisture. Journal of Agricultural Research 9: 727-742

Hubbert KR, Wohlgemuth PB, Beyers JB. 2012. Effects of hydromulch on post-fire erosion and plant recovery in chaparral shrublands of southern California. International Journal of Wildland Fire 21: $155-167$

Inbar M, Wittenberg L, Tamir M. 1997. Soil erosion and forestry management after wildfire in a Mediterranean woodland, Mt. Carmel, Israel. International Journal of Wildland Fire 7: 285-294.

Jackson ML. 1958. Soil chemical analysis, Prentice-Hall Inc.: Englewood Cliffs, New Jersey, USA.

Jordán A, Zavala LM. 2008. Soil loss and runoff rates on unpaved forest roads in southern Spain after simulated rainfall. Forest Ecology and Management 255: 913-919.

Jordán A, Zavala LM, Gil J. 2010. Effects of mulching on physical properties and runoff under semi-arid conditions in southern Spain. Catena 81: 77-85.

Keizer JJ, Coelho COA, Shakesby RA, Domingues CSP, Malvar MC, Perez IMB, Matias MJS, Ferreira AJD. 2005a. The role of soil water repellency in overland flow generation in pine and eucalypt forest stands in coastal Portugal. Australian Journal of Soil Research 43: 337-349.
Keizer JJ, Ferreira AJD, Coelho COA, Doerr SH, Malvar MC, Domingues CSP, Perez IMB, Ruiz C, Ferrari K. 2005b. The role of tree stem proximity in the spatial variability of soil water repellency in a eucalypt plantation in coastal Portugal. Australian Journal of Soil Research 43: 251-260.

Keizer JJ, Doerr SH, Malvar MC, Prats SA, Ferreira RSV, Oñate MG, Coelho COA, Ferreira AJD. 2008. Temporal variation in topsoil water repellency in two recently burnt eucalypt stands in north-central Portugal. Catena 74: 192-204.

Kim C-G, Shin K, Joo K-Y, Lee K-S, Shin S-S, Choung Y. 2008. Effects of soil conservation measures in a partially vegetated area after forest fires. Science of the Total Environment 399: 158-164.

Kraebel CJ. 1934. The La Crescenta flood. American Forest 40: 251-254.

Kramer CY. 1956. Extension of multiple range tests to group means with unequal numbers of replications. Biometrics 12: 307-310.

Kruse R, Bend E, Bierzychudek P. 2004. Native plant regeneration and introduction of non-natives following post-fire rehabilitation with straw mulch and barley seeding. Forest Ecology and Management 196: $299-310$

Larsen IJ, MacDonald LH, Brown E, Rough D, Welsh MJ, Pietraszek JH, Libohova Z, Benavides-Solorio JD, Schaffrath K. 2009. Causes of post-fire runoff and erosion: water repellency, cover, or soil sealing? Soil Science Society of American Journal 73: 1393-1407.

Leighton-Boyce G, Doerr SH, Shakesby RA, Walsh RPD. 2007. Quantifying the impact of soil water repellency on overland flow generation and erosion: a new approach using rainfall simulation and wetting agent on in situ soil. Hydrological Processes 21: 2337-2345.

Littell RC, Milliken GA, Stroup WS, Wolfinger RD. 1996. SAS®. The REG procedure. SAS Institute Inc.: Cary, NC.

Littell RC, Milliken GA, Stroup WW, Wolfinger RD, Schabenberger O. 2006. SAS for mixed models, 2nd ed. SAS Institute Inc.: Cary, NC.

Llorens P, Domingo F. 2006. Rainfall partitioning by vegetation under Mediterranean conditions. A review of studies in Europe. Journal of Hydrology 335: 37-57.

Lyles L, Dickerson JD, Schmeidler NF. 1974. Soil detachment from clods by rainfall: effects of wind, mulch cover, and initial soil moisture. Transactions of ASAE 17: 697-700.

MacDonald LH, Robichaud PR. 2007. Post fire erosion and the effectiveness of emergency rehabilitation treatments over time. Joint Fire Science Program (JFSP) Final Report 03-2-3-22. http://www.fws.gov/fire/ifcc/ Esr/Library/MacDonald\%20and\%20 Robichaud\%20JFSP\%20Final\% 20Report.pdf. (Last accessed in Accessed in June 2012].

Madsen MD, Kostka SJ, Inouye AL, Zvirzdin DL. 2012. Postfire Restoration of soil hydrology and wildland vegetation using surfactant seed coating technology. Rangeland Ecology \& Management 65: 253-259.

Maia P, Pausas JG, Arcenegui V, Guerrero C, Pérez-Bejarano A, MataixSolera J, Varela MET, Fernandes I, Pedrosa ET, Keizer JJ. 2012a. Wildfire effects on the soil seed bank of a maritime pine stand-the importance of fire severity. Geoderma 191: 80-88.

Maia P, Pausas JG, Vasques A, Keizer JJ. 2012b. Fire severity as a key factor in post-fire regeneration of Pinus pinaster (Ait.) in central Portugal. Annals of Forest Science 69: 499-507.

Malvar MC, Prats SA, Nunes JP, Keizer JJ. 2011. Post fire overland flow generation and inter rill erosion under simulated rainfall in two eucalypt stands in north-central Portugal. Environmental Research 111: 222-236.

Malvar MC, Martins MAS, Nunes JP, Robichaud PR, Keizer JJ. 2013. Assessing the role of pre-fire ground preparation operations and soil water repellency in post-fire runoff and inter-rill erosion by repeated rainfall simulation experiments in Portuguese eucalypt plantations. Catena 108: 69-83.

McIver JD, Starr L. 2000. Environmental effects of Postfire logging: literature review and annotated bibliography. General Technical Report PNW-GTR-486. U.S. Department of Agriculture, Forest Service, Pacific Northwest Research Station.

Meyer LD, Wischmeier WH, Foster GR. 1970. Mulch rates required for erosion control on steep slopes. Soil Science Society American Proccedings 34: 928-931.

Meyer LD, Dabney SM, Murphree CE, Harmon WC, Grissinger EH. 1999. Crop production systems to control erosion and reduce runoff from upland silty soils. Transactions of ASAE 42: 1645-1652.

Mulumba NL, Lal R. 2008. Mulching effects on selected soil physical properties. Soil \& Tillage Research 98: 106-111.

Munns EN. 1919. The control of flood water in southern California. Journal of Forestry 17: 423-429. 
Napper C. 2006. Burned Area emergency response treatment catalog. Watershed, Soil, Air Management 0625 1801-SDTDC. U.S. Department of Agriculture, Forest Service, San Dimas Technology and Development Center, San Dimas, CA.

Naveh Z. 1975. Degradation and rehabilitation of Mediterranean land-scapes: neotechnological degradation of Mediterranean landscapes and their restoration with drought resistant plants. Landscape Planning 2: 133-146.

Ott RL, Longnecker M. 2001. An introduction to statistical methods and data analysis, 5th ed. Duxbury Press: Garland, Texas, USA. ISBN: 0-534-25122-6

Pannkuk CD, Roubichaud PR. 2003. Effectiveness of needle cast at reducing erosion after forest fires. Water Resources Research 39: 1333. DOI: 10.1029/2003WR002318.

Peppin D, Fulé PZ, Sieg CH, Beyers JL, Hunter ME. 2010. Post-wildfire seeding in forests of the western United States: an evidence-based review. Forest Ecology and Management 260: 573-586.

Pierson FB, Moffet CA, Williams CJ, Hardegree SP, Clark PE. 2009. Prescribed-fire effects on rill and interrill runoff and erosion in a mountainous sagebrush landscape. Earth Surface Processes and Landforms 34: 193-203.

Pietraszek HP. 2006. Controls on post-fire erosion at the hillslope scale, Colorado Front Range. M.S. thesis, Colorado State University, Fort Collins, Colorado, USA.

Pinaya I, Soto B, Arias M, Díaz-Fierros F. 2000. Revegetation of burnt areas: relative effectiveness of native and commercial seed mixtures. Land Degradation and Development 11: 93-98.

Porta J, López-Acevedo M, Roquero C. 2003. Edafología para la agricultura y el medio ambiente, 3rd ed. Mundi Prensa: Madrid, Spain; 849.

Prats SA, MacDonald LH, Monteiro M, Ferreira AJD, Coelho COA, Keizer JJ. 2012. Effectiveness of forest residue mulching in reducing post-fire runoff and erosion in a pine and a eucalypt plantation in north-central Portugal. Geoderma 191: 115-124.

Rab MA. 1994. Changes in physical properties of a soil associated with logging of Eucalyptus regnans forest in southeastern Australia. Forest Ecology and Management 70: 215-229.

Robichaud PR, Brown RE. 2002. Silt fences: an economical technique for measuring hillslope soil erosion. USDA Forest Service General Technical Report RM-GTR-94, Fort Collins, CO.

Robichaud PR, Beyers JL, Neary DG. 2000. Evaluating the effectiveness of postfire rehabilitation treatments. General Technical Report RMRS GTR-63. Department of Agriculture, Forest Service, Rocky Mountain Research Station, Fort Collins, Colorado, USA. 85.

Robichaud PR, Lillybridge TR, Wagenbrenner JW. 2006. Effects of post-fire seeding and fertilizing on hillslope erosion in north-central Washington, USA. Catena 67: 56-67.

Robichaud PR, Wagenbrenner JW, Brown RE, Wohlgemuth PM, Beyers JL. 2008. Evaluating the effectiveness of contour-felled log erosion barriers as a post-fire runoff and erosion mitigation treatment in the western United States. International Journal of Wildland Fire 17: 255-273.

Robichaud PR, Ashmun LE, Sims BD. 2010. Post-fire treatment effectiveness for hillslope stabilization. General Technical Report, RMRS-GTR-240. U. S. Department of Agriculture, Forest Service, Rocky Mountain Research Station, Fort Collins, CO.
Robichaud PR, Lewis SA, Ashmun LE, Wagenbrenner JW, Brown RE. 2013a. Postfire mulching for runoff and erosion mitigation part I effectiveness at reducing hillslope erosion rates. Catena 105: 75-92.

Robichaud PR, Wagenbrenner JW, Lewis SL, Ashmun LE, Brown RE, Wohlgemuth PM. 2013b. Post-fire mulching for runoff and erosion mitigation part II: effectiveness in reducing runoff and sediment yields from small catchments. Catena 105: 93-111.

Rough D. 2007. Effectiveness of rehabilitation treatments in reducing postfire erosion after the Hayman and Schoonover fires, Colorado Fron Range. Fort Collins, CO: Colorado State University. MsC. Thesis; 186.

Shakesby RA. 2011. Post-wildfire soil erosion in the Mediterranean: review and future research directions. Earth-Science Reviews 105: 71-100.

Shakesby RA, Doerr SH. 2006. Wildfire as a hydrological and geomorphological agent. Earth-Science Reviews 74: 269-307.

Shakesby RA, Boakes JD, Coelho COA, Bento-Gonçalves JA, Walsh RPD. 1996. Limiting the soil degradational impacts of wildfire in pine and Eucalyptus forests in Portugal. Applied Geography 16: 337-355.

Smets T, Poesen J, Knapen A. 2008. Spatial scale effects on the effectiveness of organic mulches in reducing soil erosion by water. Earth-Science Reviews 89: 1-12.

SNIRH: Servico Nacional de Informacao sobre Recursos Hidricos. 2012 Boletim de Precipitação www.snirh.pt. (Last accessed in January 2012).

Soto B, Diaz-Fierros F. 1997. Soil water balance as affected by throughfall in gorse (Ulex europaeus, L.) shrubland after burning. Journal of Hydrology 195: 218-231.

Spigel KM, Robichaud PR. 2007. First-year post-fire erosion rates in Bitterroot National Forest, Montana. Hydrological Processes 21: 998-1005.

Taskey R, Curtis CL, Stone J. 1989. Wildfire, ryegrass seeding, and watershed rehabilitation. In: Proceedings of the Symposium on Fire and Watershed Management; October 1988, Sacramento, California. GTRPSW-109. U.S. Department of Agriculture, Forest Service, Pacific Southwest Forest and Range Experiment Station; 149-161.

Vila-Escalé M, Vegas-Vilarrúbia T, Prat N. 2007. Release of polycyclic aromatic compounds into a Mediterranean creek (Catalonia, NE Spain) after a forest fire. Water Research 41: 2171-2179.

Wagenbrenner JW, MacDonald LH, Rough D. 2006. Effectiveness of three post-fire rehabilitation treatments in the Colorado Front Range. Hydrological Processes 20: 2989-3006.

Wilson GV, Dabney SM, McGregor KC, Barkoll BD. 2004. Tillage and residue effects on runoff and erosion dynamics. Transactions of ASAE 47: $119-128$.

Wohlgemuth PM, Beyers JL, Hubbert KR. 2009. Rehabilitation strategies after fire: the California, USA experience. In Fire effects on soils and restoration strategies, Cerdà A, Robichaud PR (eds). Science Publishers, Inc: Enfield, NH, USA; 511-535.

Wohlgemuth PM, Beyers JL, Robichaud PR. 2011. The effectiveness of aerial hydromulch as an erosion control treatment in burned chaparral watersheds, southern California. In: Observing, studying, and managing for change-Proceedings of the Fourth Interagency Conference on Research in the watersheds. Medley N, Patterson G, Parker M (eds). Scientific Investigations Report 2011-5169: Reston, VA, USA; 162-167.

WRB: World Reference Base for Soil Resources. 2007. WRB Dominant Soil Maps. http://www.fao.org/nr/land/soils/soil/wrb-soil-maps/en/. (Accessed in February 2012). 